ЕЖОВ Дмитрий Александрович - кандидат политических наук, доцент; доцент департамента политологии факультета социальных наук и массовых коммуникаций Финансового университета при Правительстве РФ (125993, Россия, г. Москва, Ленинградский np-кт, 49; president@lenta.ru)

\title{
К АНАЛИЗУ ДИНАМИКИ ОСВЕДОМЛЕННОСТИ НАСЕЛЕНИЯ РОССИИ О НАЦИОНАЛЬНЫХ ПРОЕКТАХ
}

\begin{abstract}
Аннотация. В статье анализируется динамика осведомленности населения России о национальных проектах на 2019-2024 гг. в период с 2019 по 2020 г. В своих суждениях и выводах автор опирается на данные социологических исследований ВЦИОМа, НАФИ и Центра социального проектирования «Платформа». Отдельное внимание обращено на значимость интенсификации работы по

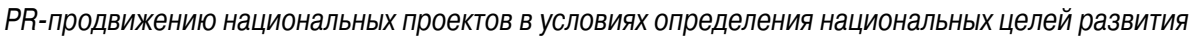
Российской Федерации на период до 2030 г.
\end{abstract}

Ключевые слова: национальные проекты, национальные цели, социологические опросы, осведомленность, узнаваемость

$\Pi$ ринятые в России в 2018 г. новые национальные проекты федерального масштаба, по задумке властей, призваны стать драйвером экономики и улучшить качество жизни россиян. В то же время степень осведомленности о национальных проектах со стороны населения фиксируется как относительно невысокая, что влечет за собой возникновение потенциальных рисков в ходе их реализации, в т.ч. имиджевого характера. Опираясь на данные социологических исследований, проведенных ВЦИОМом, НАФИ и Центром социального проектирования «Платформа», проследим динамику осведомленности населения России о национальных проектах в период 2019-2020 гг.

В феврале 2019 г. был проведен инициативный всероссийский опрос «ВЦИОМ - Спутник», в котором приняли участие 1600 чел. из 80 регионов Российской Федерации методом телефонного интервью. Результаты опроса, обнародованные генеральным директором ВЦИОМа В. Федоровым в рамках Третьего форума социальных инноваций регионов, состоявшегося в июне 2019 г., показали, что менее половины респондентов слышали словосочетание «национальные проекты». При этом хорошо знают, что оно означает, только $2 \%$ опрошенных. Лучше всего осведомлены о нацпроектах люди в возрасте от 45 до 59 лет, хуже всего - молодежь 18-24 лет. 62\% опрошенных ответили, что хотели бы получать информацию о реализации национальных проектов. Каждый десятый респондент (10\%) не интересуется тематикой нацпроектов, а $41 \%$ ответили, что не владеют информацией о национальных проектах. Среди проектов - лидеров по уровню узнаваемости - «Здравоохранение» $(25 \%)$, «Малое и среднее предпринимательство и поддержка индивидуальной предпринимательской инициативы» $(23 \%)$, «Образование» $(22 \%)$, «Экология» $(22 \%)$, «Безопасные и качественные автомобильные дороги» $(21 \%)$, «Демография» $(21 \%)$.

В мае-июне 2019 г. НАФИ и Советом Федерации ФС РФ в целях выявления степени осведомленности россиян о национальных проектах на 2019-2024 гг. было проведено исследование, в ходе которого были опрошены 1600 чел. в 150 населенных пунктах 50 регионов России. Согласно полученным данным, в общих чертах о национальных проектах имеют представление $37 \%$ опрошенных, 55\% - впервые узнали о них в ходе опроса, и всего лишь $7 \%$ подтвердили заинтересованность в ознакомлении с подробностями содержания нацпро- 
ектов. Наиболее осведомленными о национальных проектах оказались люди старшего поколения - в возрастной группе от 45 до 59 лет 50\% знают или слышали о них. В возрастных группах от 25 до 44 лет, а также старше 60 лет осведомленность находится примерно на одном уровне (38-42\%). В возрастной группе от 18 до 24 лет знают о национальных проектах только $26 \%$.

Согласно данным опроса, лучше всего респондентам известны национальные проекты «Здравоохранение» $(26 \%)$, «Образование» $(20 \%)$. Несколько ниже уровень узнаваемости у проектов «Жилье и городская среда» $(16 \%)$, «Демография» (16\%), «Экология» (14\%), «Культура» $(12 \%)$, «Малое и среднее предпринимательство и поддержка индивидуальной предпринимательской инициативы» $(11 \%)$, «Наука» $(11 \%)$. Еще меньше респонденты оказались осведомлены о нацпроектах «Безопасные и качественные автомобильные дороги» (10\%), «Цифровая экономика» $(8 \%)$, «Производительность труда и поддержка занятости» $(5 \%)$, «Комплексный план модернизации и расширения магистральной инфраструктуры» (4\%), «Международная кооперация и экспорт» $(2 \%)$.

Центром социального проектирования «Платформа» опрос проводился на базе исследовательской платформы Mail.ru Group, включающей собственную панель респондентов. Опрашивались жители РФ в возрасте от 18 лет, всего были опрошены 5000 чел. Данные опроса были обнародованы в марте 2020 г. В результате исследования констатируется невысокий уровень узнаваемости национальных проектов, объясняемый тем фактом, что накопительный эффект от реализации заложенных в них программ не сработал, а выбранные на предварительной стадии формы коммуникации респондентам не представляются оптимальными.

Согласно данным опроса, всего лишь $13 \%$ опрошенных хорошо знают о национальных проектах, 63\% - знают только в общих чертах, $24 \%$ - слышат впервые. При анализе осведомленности по возрастным группам прослеживается четкая корреляция степени осведомленности и возраста респондентов. Так, в наибольшей степени осведомлены о национальных проектах респонденты старше 55 лет, в наименьшей степени - респонденты в возрасте от 18 до 24 лет. Для наглядности заметим, что в возрастной категории старше 55 лет 16\% опрошенных хорошо осведомлены о национальных проектах, $70 \%$ - слышали о них в общих чертах, $13 \%$ - слышат впервые, в то время как в возрастной группе от 18 до 24 лет аналогичные показатели равны 11\%, 52\% и 37\% соответственно.

Проектами - лидерами по узнаваемости, согласно имеющимся данным, являются «Демография» (60\%) и «Здравоохранение» (49\%). Дальше со значительным отрывом распределяются «Жилье и городская среда» $(29 \%)$, «Образование» $(22 \%)$, «Безопасные и качественные автомобильные дороги» $(22 \%)$, «Малое и среднее предпринимательство и поддержка индивидуальной предпринимательской инициативы» (18\%), «Цифровая экономика» $(13 \%)$, «Экология» (12\%). Замыкают рейтинг узнаваемости национальные проекты «Наука» $(7 \%)$, «Культура» $(7 \%)$, «Производительность труда и поддержка занятости (6\%), «Комплексный план модернизации и расширения магистральной инфраструктуры» (3\%), «Международная кооперация и экспорт» $(1 \%)$.

На основе данных социологических опросов, полученных и обнародованных в период с февраля 2019 г. по март 2020 г., сделаем некоторые обобщения, свидетельствующие о динамике осведомленности населения России о национальных проектах.

Во-первых, следует констатировать, что процент респондентов, владеющих информацией о национальных проектах, находится на низком уровне, хотя и 
имеет тенденцию к незначительному повышению. На этом фоне фиксируется устойчивый тренд, заключающийся в том, что наиболее осведомленными о национальных проектах являются представители старших возрастных групп, а наименее информированной - молодежь.

Во-вторых, относительно стабильным является распределение национальных проектов - лидеров и аутсайдеров с точки зрения их узнаваемости среди респондентов. Характерно, что наиболее узнаваемыми являются национальные проекты, ассоциирующиеся с наиболее массовыми практиками («Демография», «Здравоохранение», «Образование»). В отношении отдельных из них наблюдается значительный рост процента узнаваемости в динамике. Однако, на наш взгляд, данный факт в большей степени обусловлен характером выборки и выбором метода проведения опроса. В то же время чрезвычайно низкими остаются показатели узнаваемости так называемых проектоваутсайдеров («Комплексный план модернизации и расширения магистральной инфраструктуры», «Международная кооперация и экспорт»).

В заключение следует признать значимость интенсификации работы по $P R$-продвижению национальных проектов в целях повышения процента осведомленности о них среди населения России, а также достижения большего эффекта узнаваемости отдельных проектов. Особый смысл данный процесс приобретает в условиях коррекции и пролонгации национальных проектов на 2019-2024 гг. вследствие подписания президентом РФ в июле 2020 г. указа «О национальных целях развития Российской Федерации на период до 2030 года».

Статья подготовлена по результатам исследований, выполненных за счет бюджетныхсредств погосударственному заданию Финуниверситету (2020).

EZHOV Dmitriy Aleksandrovich, Cand.Sci. (Pol.Sci.), Associate Professor; Associate Professor of the Department of Political Science, Faculty of Social Sciences and Mass Communications, Financial University under the Government of the Russian Federation (49 Leningradsky Ave, GSP-3, Moscow, Russia, 125993; president@lenta.ru)

\title{
TO THE ANALYSIS OF THE DYNAMICS OF AWARENESS OF THE RUSSIA'S CITIZENS ABOUT NATIONAL PROJECTS
}

\begin{abstract}
The article analyzes the dynamics of the awareness of the Russia's citizens about the national projects of 20192024 in the period from 2019 to 2020. In his judgments and conclusions, the author relies on the data of sociological research by WCIOM, NAFI and the Center for Social Design «Platform». Special attention is paid to the importance of intensifying work on PR-promotion of national projects in the context of determining the national development goals of the Russian Federation for the period up to 2030.
\end{abstract}

Keywords: national projects, national goals, opinion polls, awareness, recognition 